\title{
Chapter 7 \\ Fast-Tracking the Development and Dissemination of a Drought-Tolerant Maize Variety in Ethiopia in Response to the Risks of Climate Change
}

\author{
Berhanu T. Ertiro, Girum Azmach, Tolera Keno, Temesgen Chibsa, \\ Beyene Abebe, Girma Demissie, Dagne Wegary, Legesse Wolde, \\ Adefris Teklewold, and Mosisa Worku
}

\subsection{Introduction}

In Ethiopia, annual maize production is 7.8 million tonnes with an average yield of 3.6 tonnes per hectare $\left(\mathrm{t} \mathrm{ha}^{-1}\right)$ in 2016-the highest of any cereal in the country (Food and Agriculture Organization Corporate Statistical Database (FAOSTAT) 2017). Currently, 66\% of cereal-farming households in Ethiopia cultivate maize on 2.1 million hectares (ha), making it the second most widely cultivated cereal in the country after teff. It is estimated that each household owns around 1 ha of crop land, of which at least half is allocated for maize cultivation in major maize-growing areas. Subsistence maize farming accounts for more than $95 \%$ of the total maize area and production, with $75 \%$ of all maize produced being consumed by the farming household (Abate et al. 2017).

Ethiopia started growing hybrid maize relatively late, even by African standards (Harrison 1970, Tolessa et al. 1993). Early maize research in Ethiopia focused on the identification of locally adapted open-pollinated varieties (OPVs) to replace low yielding, tall and lodging susceptible landraces. The national hybrid maize breeding programme in Ethiopia was launched in the early 1980s, targeting four major maize growing agro-ecologies: mid-altitude sub-humid, highland sub-humid, lowmoisture stress, and lowland sub-humid maize agro-ecologies. A top-cross hybrid variety, BH140, was released for the mid-altitude sub-humid agro-ecology in 1988 (Tolessa et al. 1993). A late maturing three-way cross hybrid, BH660, adapted to the mid-altitude moist and transitional highland maize agro-ecologies was released in

B. T. Ertiro $(\bowtie) \cdot$ G. Azmach · T. Keno · T. Chibsa · B. Abebe · G. Demissie · L. Wolde Ethiopian Institute of Agricultural Research, Addis Ababa, Ethiopia

D. Wegary $\cdot$ A. Teklewold

Centro Internacional de Mejoramiento de Maíz y Trigo (CIMMYT), Addis Ababa, Ethiopia

M. Worku

CIMMYT, Nairobi, Kenya

T. S. Rosenstock et al. (eds.), The Climate-Smart Agriculture Papers, https://doi.org/10.1007/978-3-319-92798-5_7 
1993; and, later, another intermediate-maturing single-cross hybrid, BH540, adapted to the mid-altitude moist maize agro-ecology was released in 1995. The launch of the National Extension Intervention Program in 1993 by the Ethiopian Government, in partnership with Sasakawa Global 2000, played a key role in the popularisation and dissemination of these hybrids (Worku et al. 2012; Abate et al. 2015). In the period 2002-2010, the three hybrids accounted for over $90 \%$ of total maize seed sales (35,000 tonnes) by the Ethiopian Seed Enterprise (ESE) - the primary public seed supplier in Ethiopia. BH660 constituted over 55\% of total hybrid seed sales (Worku et al. 2012).

\subsection{Climate Change and Drought in Ethiopia}

The average age of current maize varieties under production in Ethiopia is 11 and 18 years for hybrids and OPVs respectively (Abate et al. 2017). On average, 80\% of maize varieties commonly grown in Ethiopia were developed using germplasm not improved for drought tolerance over 20 years ago (Abate et al. 2015).

As for many countries of sub-Saharan Africa (SSA), climate change projections for Ethiopia suggest an increase of maximum and minimum temperatures and a decreasing trend in precipitation (Deressa 2007). Since 1971, Ethiopia has experienced eight drought episodes of varying severity due to reduced rains in different parts of the country (Viste et al. 2012). These episodes lasted from a single year to 4 years in duration. In general, decline in precipitation has been observed in southern Ethiopia during both the February-May and June-September seasons, although a similar trend was not observed in the central and northern highlands. The study by Viste et al. (2012) found 2009 to be an exceptionally severe drought year, and the second driest year overall in the period 1971-2011, surpassed only by the historic drought of 1984. The study also revealed increasing frequency of spring (FebruaryMay) droughts in all parts of the country in recent years. Despite highly variable rainfall, Ethiopia relies on a rain-fed agriculture with irrigated areas accounting for only $1 \%$ of the total maize area (Abate et al. 2015). This makes Ethiopian agricultural system highly vulnerable to drought events as was clearly demonstrated recently during the 2016 drought, caused by El Niño, that severely affected maize production.

Breeding and disseminating drought- and heat-tolerant, climate-smart maize varieties can play a major role in mitigating the risks of droughts today as well as projected climate change in Ethiopia. Old varieties that are currently in commercial production were not selected for drought tolerance and are less likely to be adapted to future climates. CIMMYT, in collaboration with national agricultural research programmes in SSA, has been intensively developing drought-tolerant (DT) varieties that are also high-yielding under optimum conditions. These new DT varieties should replace old popular varieties to minimise the risk of climate change on productivity. 
BH660 is the most popular maize hybrid in Ethiopia but is over 20 years old and was not developed for drought tolerance. Between 2010 and 2012, annual certified seed production of this variety peaked at 6000 tonnes - an amount sufficient to cover more than 240,000 ha. Replacing the dominant but ageing crop varieties with new climate-smart varieties is a critical step in reducing the risks of climate change in SSA.

\subsection{Research Efforts to Develop New Hybrids}

The Ethiopian maize breeding programme was initiated in 1952 by first collecting germplasm from various national and international sources (Tolessa et al. 1993). The programme later focused on using germplasm of East African origin, owing to agro-ecological similarity (Harrison 1970; Tolessa et al. 1993). BH660 was developed using early generation inbred lines (Harrison 1970; Tolessa et al. 1993; Ertiro et al. 2015) derived from Kitale Synthetic II and ECU573. The current breeding strategy is to exploit CIMMYT, International Institute of Tropical Agriculture, and locally developed inbred lines - separately or in combination-to develop new DT hybrids in Ethiopia.

Because of its wide cultivation and popularity, the replacement of BH660 with a DT variety was considered crucial to address the increased frequency of drought as a result of climate change in Ethiopia. The first approach was aimed at replacing only the female parent of the single cross (SC) seed parent of BH660 with CIMMYT DT inbred lines, and then replacing the third (male) parent with other ECU573derived inbred lines. This, however, was not successful as none of the hybrids outyielded the commercial checks. The second approach focused on a complete replacement of the SC seed parent with a CIMMYT DT SC tester with excellent general combining ability for drought stress, while maintaining the original male parent. Over a period of 4 years (2006-2009), 9-12 hybrid combinations were tested in more than 30 optimum and random drought environments (Table 7.1). Among the tested hybrids, BH661 consistently outperformed the commercial checks (BH660 and BH670) in most trial sites. In head-to-head comparison, BH661 showed an average grain-yield advantage (GYA) of $10.2 \%$ and $12.9 \%$ over BH660 and $\mathrm{BH} 670$, respectively. The new hybrid also showed an average of $2 \%$ reduction in plant height, $6 \%$ reduction in ear placement and, crucially, $34 \%$ reduction in lodging over BH660 (Fig. 7.1).

\subsubsection{Release and Adoption of BH661}

Unlike the established practice of embarking on variety demonstration only following official release, breeders conducted popularisation, demonstration and pilot seed production concurrently with the variety verification trial of BH661. The variety verification trial is the final stage of variety evaluation in Ethiopia, whereby 
Table 7.1 Head-to-head comparison of BH661 with BH660 and BH670 for grain yield in different sets of trials conducted at eight mid-altitude, transitional highland and true highland subhumid maize agro-ecologies of Ethiopia during 2006-2011

\begin{tabular}{|c|c|c|c|c|c|c|c|c|}
\hline \multirow[b]{2}{*}{ Location } & \multirow{2}{*}{$\begin{array}{l}\text { Altitude } \\
\text { (masl) }\end{array}$} & \multirow{2}{*}{$\begin{array}{l}\text { Annual } \\
\text { rainfall } \\
(\mathrm{mm})\end{array}$} & \multirow{2}{*}{$\begin{array}{l}\text { Number of } \\
\text { trials }\end{array}$} & \multicolumn{3}{|c|}{ Mean grain yield } & \multicolumn{2}{|c|}{$\%$ GYA over } \\
\hline & & & & BH661 & BH660 & BH670 & BH660 & BH670 \\
\hline Bako & 1650 & 1211 & 6 & 9.79 & 9.43 & 9.07 & $3.8 \%$ & $7.9 \%$ \\
\hline Hawassa & 1708 & 945 & 5 & 10.79 & 9.39 & 8.39 & $14.8 \%$ & $28.5 \%$ \\
\hline Areka & 1750 & 1401 & 5 & 6.82 & 6.50 & 6.57 & $5.0 \%$ & $3.8 \%$ \\
\hline $\begin{array}{l}\text { Arsi } \\
\text { Negelle }\end{array}$ & 1940 & 900 & 6 & 7.83 & 8.19 & 8.09 & $-4.4 \%$ & $-3.1 \%$ \\
\hline Jimma & 1725 & 1448 & 6 & 10.56 & 8.71 & 8.54 & $21.3 \%$ & $23.6 \%$ \\
\hline Adet & 2203 & 1118 & 4 & 8.10 & 7.87 & 7.12 & $2.9 \%$ & $13.8 \%$ \\
\hline $\begin{array}{l}\text { Finote } \\
\text { Selam }\end{array}$ & 1853 & 1125 & 3 & 8.84 & 7.81 & 9.09 & $13.2 \%$ & $-2.8 \%$ \\
\hline Haramaya & 2015 & 820 & 2 & 11.61 & 8.60 & 9.45 & $35.0 \%$ & $22.9 \%$ \\
\hline Across & & & & 9.09 & 8.25 & 8.06 & $10.2 \%$ & $12.9 \%$ \\
\hline
\end{tabular}

Source: Bako National Maize Research Center; altitude and annual rainfall (Worku et al. 2012) masl metres above sea level, $\mathrm{mm}$ millimetres

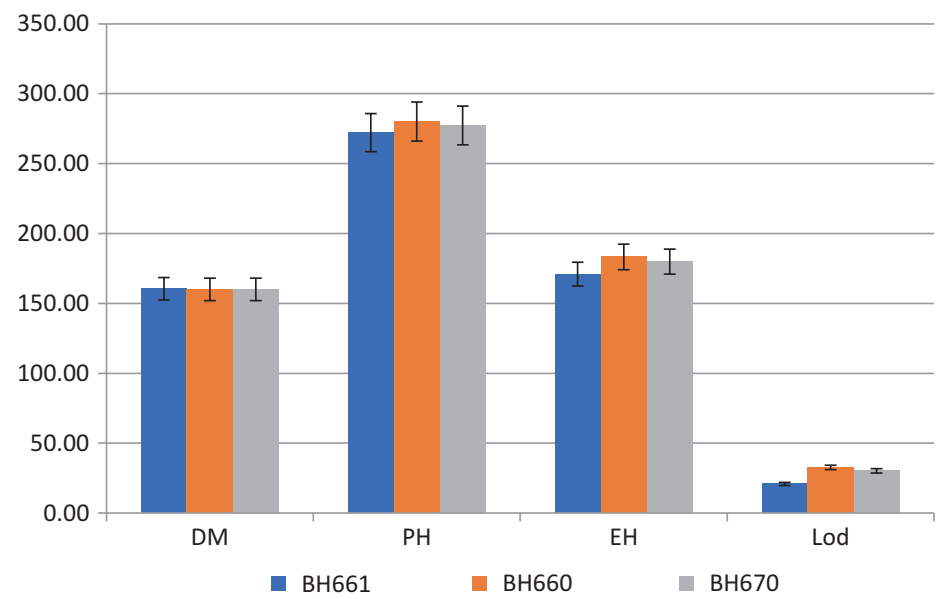

Fig. 7.1 Head-to-head comparison of BH660, BH661 and BH670 for secondary traits evaluated at Bako, Hawasa, Areka, Arsi Negele, Finote Selam and Jimma during 2006-2011; DM (days to maturity); PH (plant height); EH (ear height); Lod (lodging); error bars show $\pm 5 \%$

candidate varieties are compared with the current commercial checks on large plots $(10 \times 10 \mathrm{~m})$ on research stations and farmers' fields. The plots are evaluated by an ad hoc Technical Variety Release Committee which incorporates farmers' perspectives. The promotion of BH661 began through farmers' participatory variety selection (PVS) with financial support from various CIMMYT-managed projects. 


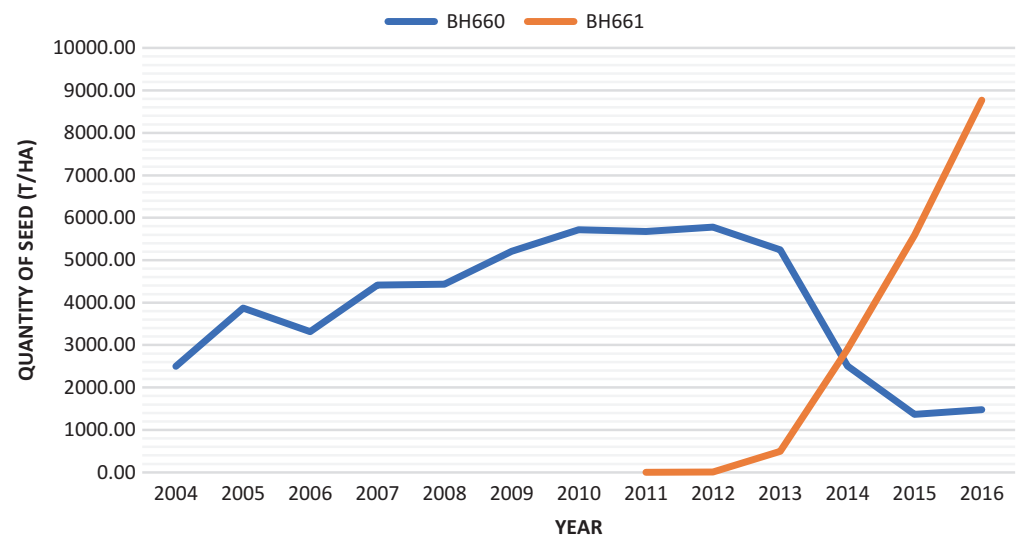

Fig. 7.2 Comparison of the amount of certified seed production of BH660 and BH661 from 2012 to 2016. (Source: compiled by the authors)

Farmers and other stakeholders who took part in the variety evaluation consistently ranked BH661 first for on-farm grain yield, maturity, prolificacy, standability, uniformity and biomass yield. In 2011, the National Variety Release Standing Committee officially approved the release of BH661 for commercial cultivation in the mid-altitude sub-humid and transition highland maize growing areas (Worku et al. 2012). Farmers who were impressed by the outstanding performance of BH661 during the verification and PVS trials started to demand its seed immediately, forcing seed companies to quickly scale-up certified seed production.

At the end of 2011, Bako National Maize Research Center supplied 400 kilogrames $(\mathrm{kg})$ of breeder seed of each of the parental lines, and $450 \mathrm{~kg}$ of the SC parent to five certified seed producers - namely, Amhara Seed Enterprise (ASE), Bako Agricultural Research Center (BARC), ESE, Oromia Seed Enterprise (OSE) and South Seed Enterprise (SSE). The Center also produced and distributed 1.7 tonnes of certified seed to seed companies, agricultural offices, research centres and nongovernmental organizations who were interested in popularising the new hybrid. In addition, the breeders of BH661 established demonstration plots, organised farmers' field days and intensively used public television stations to promote the hybrid in the two most widely spoken Ethiopian languages, Amharic and Afaan Oromo. By 2012, many institutions were actively promoting BH661, while four of them (BARC, ESE, OSE and SSE) had already begun producing basic seed. ESE produced 6.0 tonnes of certified seed, which was enough to cover 240 ha. By 2014, five companies - namely ASE, Avallo, ESE, OSE, and SSE-produced nearly 2900 tonnes of certified seed (Abate et al. 2015). This rose to almost 9000 tonnes by 2016 (Fig. 7.2). This concerted effort by the national maize research and extension programmes in Ethiopia, along with various national and international stakeholders, was instrumental in fast-tracking the dissemination and adoption of the new DT hybrid. 


\subsubsection{How Were Farmers Convinced About the Superior Performance of BH661?}

In 2012, when the national maize research programme and other institutions embarked on large-scale popularisation of BH661 across the country, major maize growing areas - including western and southern Ethiopia-experienced drought, by coincidence during the main growing season. In most places, the onset of rains was delayed and ceased well before grain filling, which affected maize yields especially for late-maturing varieties such as BH660. During that season, the Bako National Maize Research Center had established several on-farm demonstration plots to showcase the performance of BH661 against BH660. Local farmers and other stakeholders from across the country converged at one of the on-farm demonstration sites in a village called Abakora to witness the superior performance of BH661, which was planted alongside BH660 on $400 \mathrm{~m}^{2}$ plot. The participants clearly noticed the drought tolerance of BH661 and were convinced of its superiority relative to BH660.

In the same year, demonstration plots established by the SSE in the Hawassa area were also affected by drought, similarly convincing the Enterprise of the superior drought tolerance of BH661; thus fast-tracking large-scale seed production and marketing of BH661 in southern Ethiopia. From similar observations on demonstrations plots throughout the country in 2012, various key stakeholders were convinced that BH661 was a better option than BH660.

\subsection{Outcome of the Replacement Activities}

In 2016, nearly 9000 tonnes (Fig. 7.2) of certified seed of BH661 was produced and marketed by various seed producers in Ethiopia. From the current estimated $55 \%$ of maize area planted to improved seed, seed production of BH661 was sufficient to cover 360,000 ha $(18 \%$ of the total maize area, or about $30 \%$ of maize area under improved seed). Improved seed in Ethiopia is produced and marketed by public seed companies (60\% market share), local private seed companies (10\% market share) and multinational seed companies with proprietary hybrids (30\% market share). Public seed companies dominate the market due to incentives from the Government that include royalty-free licensing of public hybrids and access to state-owned land for seed production. As a result, hybrid seed price in Ethiopia is affordable (estimated at less than 1 United States Dollar per kg) to the small-scale farmer. Credit facilities are also available to the poorest farmers through farmers' cooperative unions for the purchase of seed and fertiliser, which is repaid after harvest.

Key to driving the adoption of BH661 was the willingness of seed companies to produce and market the new hybrid and withdraw BH660. Three key producibility features of BH661 were critical in driving the adoption of the hybrid by seed 
companies: disease- and drought-tolerance of the new SC seed parent which resulted in higher seed yields and, therefore, lower cost of goods; similar female and male planting splits to BH660, which meant that production systems did not need to be modified to accommodate production of BH661; and, having the same male parent as BH660, which meant both hybrids could be produced in proximal areas.

As of 2017, there remains high demand for BH661. Seed demand is recorded by development agents. Demand is compiled at district and zonal levels, which is later passed on to the regional Bureau of Agriculture and Natural Resources (BoANR) and finally to the Ministry of Agriculture and Natural Resources (MoANR). Seed produced by diverse seed growers, including public and private seed companies as well as farmers' cooperative unions, is reported to BoANR and MoANR. Finally, BoANR and MoANR are responsible to match demand and supply.

\subsection{Conclusion and Implications for Development}

The narrow genetic base of late-maturing germplasm adapted to East Africa has long hampered the development of DT varieties that could replace BH660-the dominant maize hybrid in Ethiopia for the last 25 years. Free access to DT maize germplasm from CIMMYT enabled breeders to develop new DT maize hybrid combinations that better yield under both moisture-stress and optimum conditions. The introduction of new DT varieties, like BH661, into stress-prone maize farming systems has contributed to improved productivity and food subsistence in Ethiopia. Better seed producibility parameters of the parents of BH661, compared to BH660, resulted in rapid adoption of the hybrid by the seed sector. The successful development and commercialisation of BH661 can serve as a valuable case study for breeders, seed companies, extension agents, regulatory and policy makers in how to aggressively replace ageing crop varieties with new climate-smart varieties. Success with BH661 was due to a higher grain yield than BH660 under DT conditions, the disease resistance and DT characteristics of its SC seed parent and the involvement of various stakeholders in popularising the variety. Nonetheless, an overreliance on a single new mega-variety presents risks and, therefore, the development and release of new climate-smart varieties should be a continuous process. Though the public-sector played a crucial role in the dissemination of BH661, this may not be sustainable in all instances and increased participation of the private-sector is likely to play a vital role in the dissemination of climate-smart varieties in SSA.

Acknowledgements Financial support from the Government of Ethiopia and various CIMMYTmanaged projects (e.g. Drought Tolerant Maize for Africa and the Sustainable Intensification of Maize-Legume Cropping Systems for Food Security in Eastern and Southern Africa) are highly appreciated. All maize collaborating centres in Ethiopia are especially acknowledged for their data collection. 


\section{References}

Abate T, Shiferaw B, Menkir A et al (2015) Factors that transformed maize productivity in Ethiopia. Food Secur 7:965-981

Abate T, Fisher M, Abdoulaye T et al (2017) Characteristics of maize cultivars in Africa: how modern are they and how many do smallholder farmers grow? Agric Food Secur 6:30

Deressa T (2007) Measuring the economic impact of climate change on Ethiopian agriculture: Ricardian approach, World Bank policy research paper no. 4342. World Bank, Washington, DC

Ertiro B, Ogugo V, Worku M et al (2015) Comparison of Kompetitive Allele Specific PCR (KASP) and genotyping by sequencing (GBS) for quality control analysis in maize. BMC Genomics 16:908

Food and Agriculture Organization Corporate Statistical Database (2017). Statistical databases and data sets of FAOSTAT. http://faostat.fao.org/default.aspx. Accessed 18 Dec 2017

Harrison MN (1970) Maize improvement in East Africa. In: Leakey CLA (ed) Crop improvement in East Africa. Commonwealth Agricultural Bureaux, Farnham Royal, pp 27-36

Tolessa B, Gobezayehu T, Worku M et al (1993) Genetic improvement of maize in Ethiopia. In: Tolesa B, Ranson JK (eds) Proceedings of the first national maize workshop of Ethiopia. May 5-7 1992. IAR/CIMMYT, Addis Ababa, pp 13-22

Viste E, Korecha D, Sorteberg A (2012) Recent drought and precipitation tendencies in Ethiopia. Theoretical and Applied Climatology 112(3-4):535-551

Worku M, Twumasi-Afriyie S, Wolde L et al (2012) Meeting the challenges of global climate change and food security through innovative maize research: proceedings of the third national maize workshop of Ethiopia. EIAR/CIMMYT, Addis Ababa

Open Access This chapter is licensed under the terms of the Creative Commons Attribution 4.0 International License (http://creativecommons.org/licenses/by/4.0/), which permits use, sharing, adaptation, distribution and reproduction in any medium or format, as long as you give appropriate credit to the original author(s) and the source, provide a link to the Creative Commons license and indicate if changes were made.

The images or other third party material in this chapter are included in the chapter's Creative Commons license, unless indicated otherwise in a credit line to the material. If material is not included in the chapter's Creative Commons license and your intended use is not permitted by statutory regulation or exceeds the permitted use, you will need to obtain permission directly from the copyright holder.

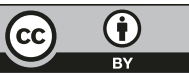

